\title{
NR5A2 Gene
}

National Cancer Institute

\section{Source}

National Cancer Institute. NR5A2 Gene. NCI Thesaurus. Code C112510.

This gene is involved in ligand-dependent transcriptional regulation. 